\title{
DENTAL DEVELOPMENT AND ONTOGENETIC DIET SHIFTS OF Roeboides paranensis Pignalberi (OSTEICHTHYES, CHARACINAE) IN POOLS OF THE UPPER RIO PARANÁ FLOODPLAIN (STATE OF PARANÁ, BRAZIL)
}

\author{
HAHN, N. S., ${ }^{1,2}$ PAVANELLI, C. S. ${ }^{1}$ and OKADA, E. K. ${ }^{1}$ \\ ${ }^{1}$ Nupélia (Núcleo de Pesquisas em Limnologia, Ictiologia e Aqüicultura), Universidade Estadual de Maringá, \\ Av. Colombo, 5790, CEP 87020-900, Maringá, Paraná, Brazil \\ ${ }^{2}$ Departamento de Biologia, Universidade Estadual de Maringá, Av. Colombo 5790, CEP 87020-900, \\ Maringá, Paraná, Brazil \\ Correspondence to: Norma Segatti Hahn, Nupélia (Núcleo de Pesquisas em Limnologia, Ictiologia e \\ Aqüicultura), Universidade Estadual de Maringá, Av. Colombo, 5790, CEP 87020-900, Maringá, Paraná, \\ Brazil, e-mail: hahnns@nupelia.uem.br \\ Received November 30, 1998 - Accepted June 15, 1999 - Distributed February 28, 2000
}

(With 5 figures)

\begin{abstract}
Species of the characid genus Roeboides are known for their habit of tearing off and ingesting scales from other fishes. Specimens of Roeboides paranensis were taken monthly from March 1992 through February 1993 in five pools of the upper Rio Paraná floodplain and in one site in the Rio Paraná itself, with the aim of relating the dental development to ontogenetic diet shifts. Between 15-22 mm SL, fish had teeth with hypertrophied bases (mammiform) that moved to the outside of the mouth in both maxillas. During ontogeny, the diet shifted, with the smallest individuals eating more microcrustaceans and the larger ones eating more scales. Lepidophagy is non-obligatory, because the ingestion of insects and other invertebrates occurred at all sizes. Spatial variation in diet was large, however diet similarity was great for Roeboides from three floodplain pools that had similar proportions of the main diet categories.
\end{abstract}

Key words: Roeboides paranensis, dental development, diet shifts, Rio Paraná.

\section{RESUMO}

\section{Desenvolvimento dentário e variações ontogenéticas na dieta de Roeboides paranensis Pignalberi (Osteichthyes, Characinae) em lagoas da planície de inundação do alto rio Paraná (Estado do Paraná, Brasil)}

Espécies de caracídeos do gênero Roeboides são conhecidas por seu hábito de arrancar e ingerir escamas de outros peixes. Exemplares de Roeboides paranensis foram capturados mensalmente de março de 1992 a fevereiro de 1993 em cinco lagoas da bacia do alto rio Paraná e em um ponto na calha do rio Paraná, com o objetivo de relacionar o desenvolvimento dentário com alterações ontogenéticas na dieta. Entre 15-22 mm de comprimento-padrão, os peixes apresentam dentes com bases hipertrofiadas (mamiliformes), que migram para fora da boca em ambas as maxilas. Durante o desenvolvimento, a dieta altera-se, com os exemplares menores ingerindo mais microcrustáceos e os maiores alimentando-se mais de escamas. A lepidofagia nessa espécie é facultativa, pois a ingestão de insetos e outros invertebrados ocorre em exemplares de todos os tamanhos. Variações espaciais na dieta foram marcantes, entretanto os maiores valores de similaridade em três das lagoas estudadas devem-se à semelhança nas proporções do alimento principal.

Palavras-chave: Roeboides paranensis, desenvolvimento dentário, alterações na dieta, rio Paraná. 


\section{INTRODUCTION}

Species of the genus Roeboides are widely distributed in the Neotropical region, and are known for their habit of tearing off and ingesting scales from other fishes, a behavior termed lepidophagy. This type of mutilating predation is also known in many species of the Characoidei (Géry, 1977), and is more frequent in tropical species (Sazima \& Machado, 1982).

Feeding habits can be understood better by examining functional morphology. Intra-specific shifts in diet have been documented for many fishes, and shifts often are accompanied by changes in morphological characteristics. Roberts (1967) commented that in many species, the morphology of the functional dentition differs profoundly between juveniles and adults. Like other species of the genus, Roeboides paranensis Pignalberi, 1975, the "dentudo", has external teeth (Miquelarena, 1986) that are used to remove scales.

In the present work, we establish through examination of the diet and the extent to which this species makes use of its morphological attributes to obtain food (scales). We also evaluate possible ontogenetic and spatial changes in the composition of its food.

\section{MATERIAL AND METHODS}

The area studied is located on two islands in the upper Rio Paraná, in the region of Porto Rico in the northwestern part of the State of Paraná. In this stretch, the river may be as much as $14 \mathrm{~km}$ wide, with an extensive floodplain on its right margin. Five pools were sampled in this investigation (Fig. 1): Pontal, Canal do Meio, Pau Velho, Porto Rico, and Três Amigos; and one station in the Rio Paraná. These pools vary in size, position and degree of connection with the main channel of the Rio Paraná according to its hydrological regime. Some of them remain in contact with the main channel throughout the year. The pools also differ in substrate, bank vegetation, exposure to light, aquatic vegetation, and cover (Okada, 1995).

Fish samples were taken monthly in the five pools from March 1992 through February 1993. In the Rio Paraná, a single sample was taken in November 1992, to obtain larger individuals in order to complement the analysis.

Specimens were captured using $20 \mathrm{~m}$-long seine nets (10 mm meshes), measured and weighed, fixed in $10 \%$ formalin, and preserved in $70^{\circ} \mathrm{GL}$ alcohol. Ten specimens of each size class (19-34, $35-50,51-66$, and 67-82 $\mathrm{mm} \mathrm{SL}$ ) were used for dental descriptions.

The teeth were counted and a specimen of each size class was drawn using a drawing tube attached to a dissecting microscope, and another specimen cleared and stained according to the technique of Taylor (1967) and Dingerkus \& Uhler (1977), modified by Potthoff (1984), to verify the presence or absence of tooth buds. The contents of 744 stomachs were analyzed by the frequency of occurrence method (Hynes, 1950), and the items identified to lowest possible taxonomic level.
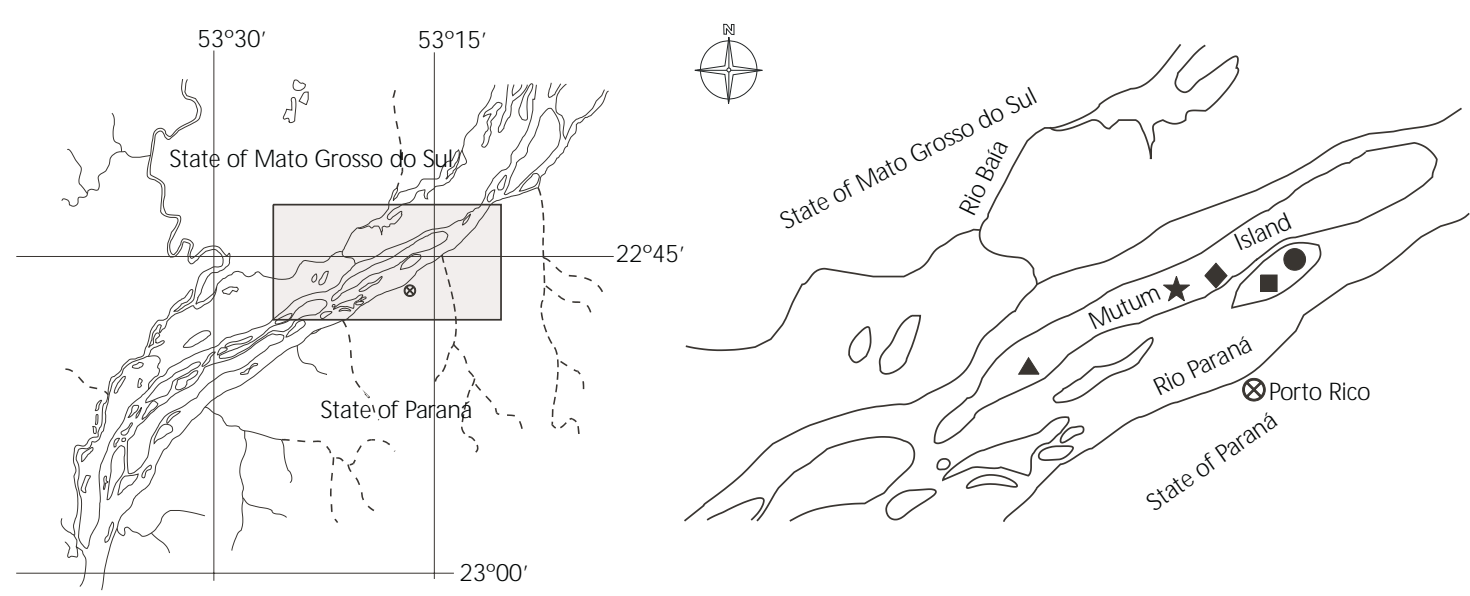

Fig. 1 - Sampling locations

Três Amigos;

: Porto Rico;

: Pau Velho;

: Canal do Meio;

: Pontal). 
For comparison of tooth morphology with diet, the items were grouped as: microcrustaceans, insects, scales, and other.

The diet similarity in the different pools was obtained by applying a grouping analysis to a matrix of 22 (food categories) X 6 (sites) using Euclidean distance and UPGMA (unweighted pairgroup average) as the linking method.

\section{RESULTS}

\section{Dental development}

The premaxillary, maxillary and dentary teeth in the four developmental stages considered, are shown in Fig. 2 and described as follows:
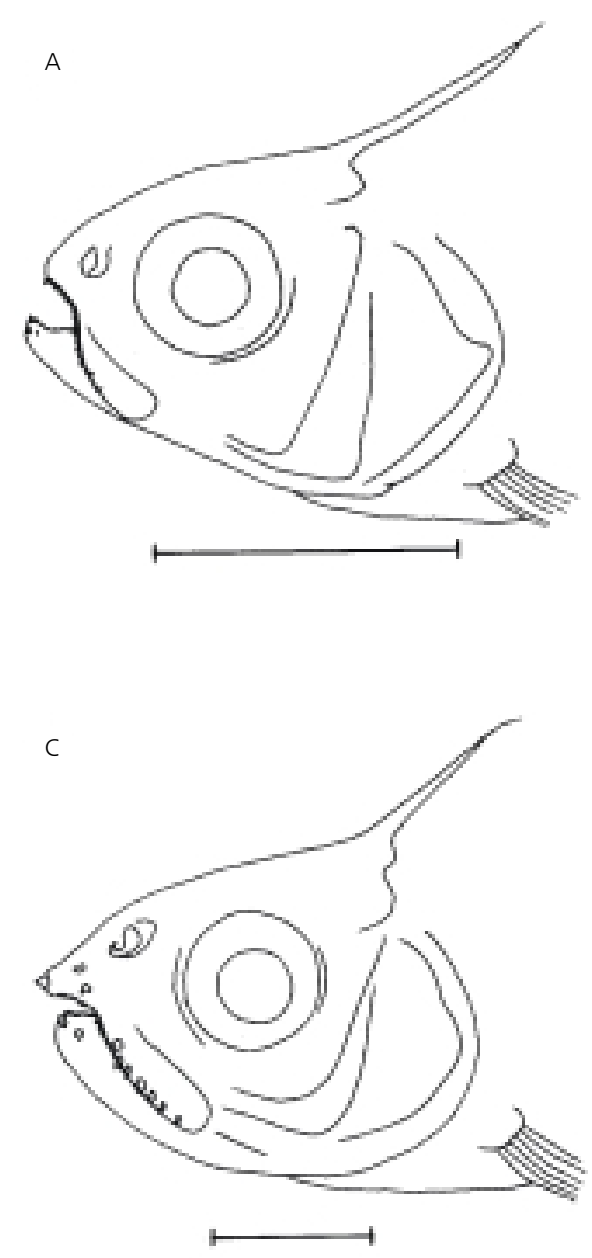

Premaxillary: In the smallest individuals (up to $22 \mathrm{~mm}$ ), the anterior region, next to the symphysis has the normal aspect of other Characinae (e.g. Charax spp., Characidae), with the mouth terminal. Up to this length, individuals possess a series of conical teeth inside the mouth, one or two of these being larger and located next to the symphysis, and three to nine smaller, more lateral teeth. As the fish develops, gradually the anterior region of the bone begins to project forward, becoming more protuberant. Concomitantly, some of these teeth move outside the mouth. The process is initiated by one tooth of the middle region, followed by one nearer the articulation of this bone with the maxillary, and finally, by a tooth next to the symphysis.
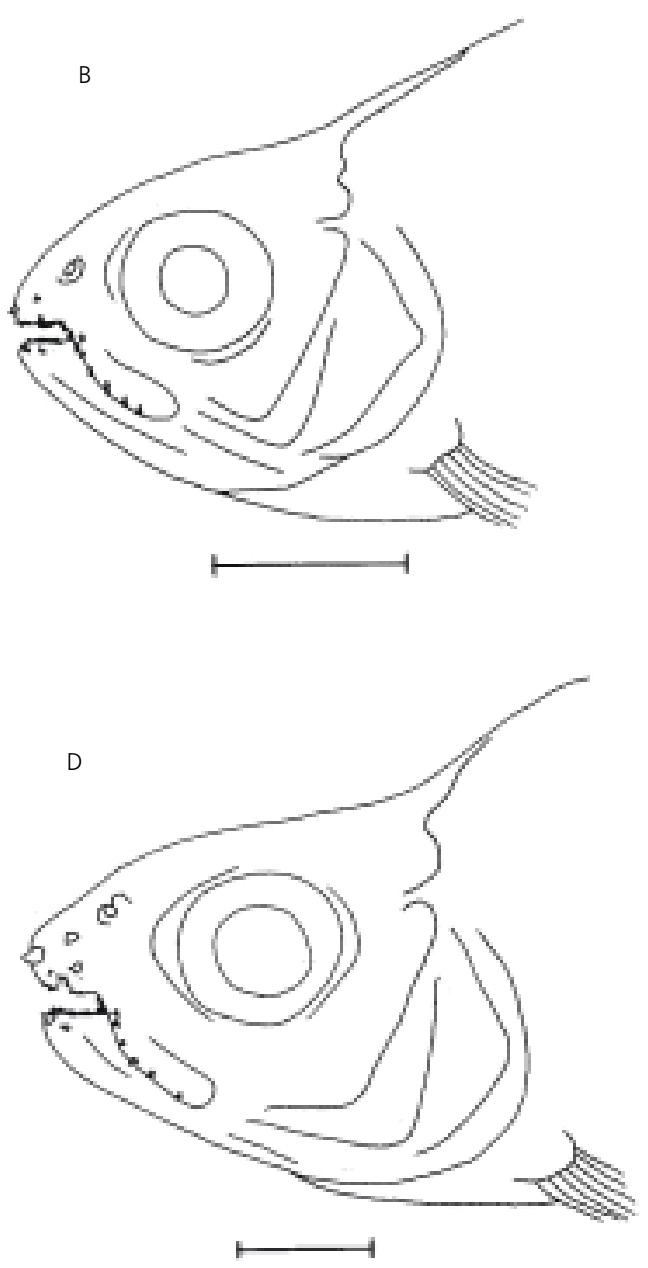

Fig. 2 - Dental morphology of Roeboides paranensis at different sizes: $A=31.6 \mathrm{~mm} ; \mathrm{B}=45.0 \mathrm{~mm} ; \mathrm{C}=57.0 \mathrm{~mm}$; $\mathrm{D}=73.8 \mathrm{~mm}$. Scale bar: $50 \mathrm{~mm}$. 
These large teeth, with hypertrophied bases (mammiform), appear larger and more exterior as the individual fish grow.

Maxillary: In the smallest individuals, this bone bears from three to nine small conical teeth, arranged regularly on its anterior edge, in the region nearest its articulation with the premaxillary. Five to nine of the larger conical teeth are arranged, spaced farther apart, on the distal part of the anterior edge of this bone. In individuals longer than $40 \mathrm{~mm}$, between these two types of teeth, one or two of the former type move slightly toward the outside, and these become larger and more mammiform as the individuals grow.

Dentary: On this bone, even in small individuals (up to $25 \mathrm{~mm} \mathrm{SL}$ ), there are already one or two teeth that have moved outside the mouth: a larger mammiform tooth near the symphysis, and another smaller tooth on the more lateral part. Only individuals shorter than $30 \mathrm{~mm}$ have these teeth in the normal position.
Within the mouth, in individuals of every size class, the teeth are arranged in the following manner: one or two large teeth next to the symphysis, followed laterally by three to five smaller teeth, another large tooth (somewhat mammiform), and latero-posteriorly by a regular row of up to 12 small conical teeth.

\section{Ontogenetic diet shifts}

The Fig. 3 illustrates the composition of food (main food groups) in the four size classes. The ingestion of scales increased considerably with size, varying in occurrence from $17.6 \%$ in the smallest individuals to $73.3 \%$ in the largest. Microcrustaceans were consumed more by small specimens and were less important in the diet as the fish grow, varying from $92.3 \%$ of the diet of the smallest fish to $36.7 \%$ for the largest specimens. Insects, on the other hand, were frequent in the diet of all size classes, except for individuals smaller than $34 \mathrm{~mm}$.

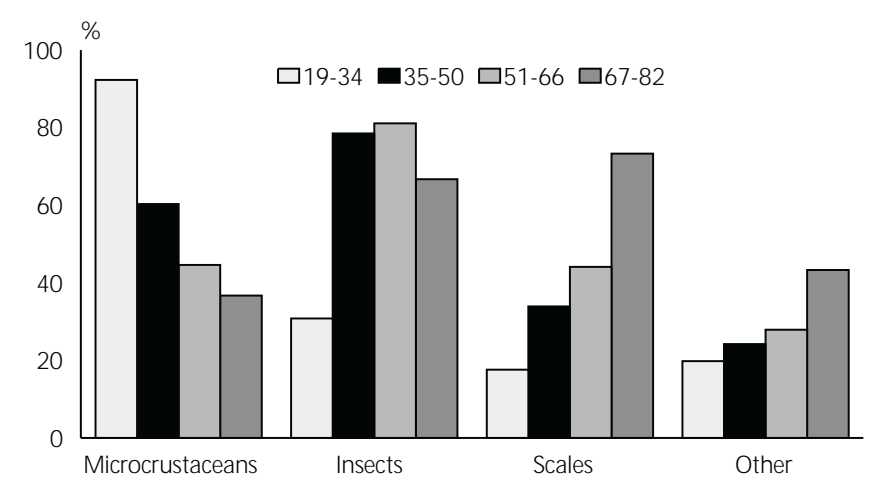

Fig. 3 - Frequency of occurrence of principal diet categories for Roeboides paranensis in four size classes (in mm).

\section{Spatial variation in diet}

Roeboides paranensis included different groups of aquatic organisms in its diet; however, microcrustaceans, insects, and scales dominated in the stomach contents (Fig. 4).

In the Rio Paraná, the food was less varied than in the pools, and the main item was microcrustaceans. Insects were prominent in the diet in the pools. In Pontal, insects represented $75.0 \%$ of the diet, in Canal do Meio $85.4 \%$, in Pau Velho $89.2 \%$, and in Porto Rico $83.0 \%$. In Três Amigos, insects and microcrustaceans were con- sumed in similar proportions, $68.2 \%$ and $64.2 \%$, respectively. Hemiptera (Gerridae) followed by Diptera (mainly Chironomidae) were prominent constituents of the diet in all the pools.

Cladocerans were the most frequently consumed microcrustaceans, except in the Rio Paraná and Pool Três Amigos, where copepods attained the highest percentages. Scales were recorded in the stomachs in similar proportions in the six locations, however they were more frequent in stomachs of individuals from Canal do Meio $(45.8 \%)$. 


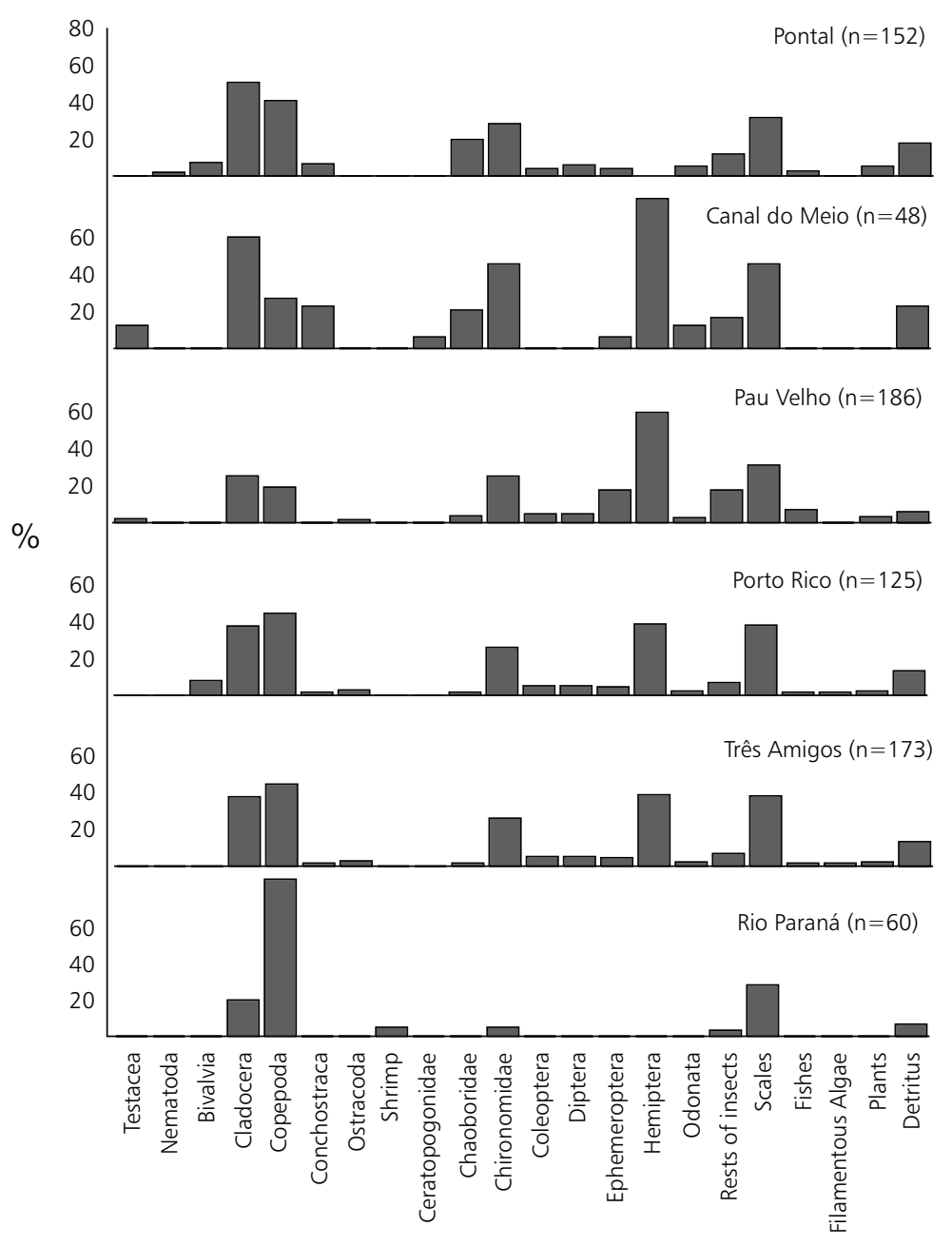

Fig. 4 - Frequency of occurrence of different diet categories for Roeboides paranensis at five pools and one site in the Rio Paraná.

Cluster analysis by locations (Fig. 5) showed the highest similarity values for the food of fish of pools Pontal and Porto Rico. These were followed by Três Amigos and a cluster of three sites, Pau Velho, Canal do Meio, and the Rio Paraná.

\section{DISCUSSION}

Ontogenetic morphological changes, such as form, number, and arrangement of the teeth of different characoids, were described by Roberts (1967). Morphological changes in accordance with the development of individuals were observed for the "dentudo", mainly regarding the mammiform teeth, which migrated outside of the mouth in specimens larger than $22 \mathrm{~mm}$. Analysis of cleared and stained specimens confirmed the absence of tooth buds where the mammiform teeth are found, so that dislocation of these teeth is the most probable hypothesis to explain their origin outside of the mouth. As the teeth become more exterior, larger, and therefore more functional, they accompany a gradual change in the feeding habits of this species. The "dentudo" eats more scales as it grows, although it does not stop consuming other food items, thus indicating that lepidophagy is facultative in this species. Other investigators have found similar results for different species of Roeboides (Roberts, 1970; Sazima \& Machado, 1982; Sazima, 1983; Peterson \& Winemiller, 1997). 


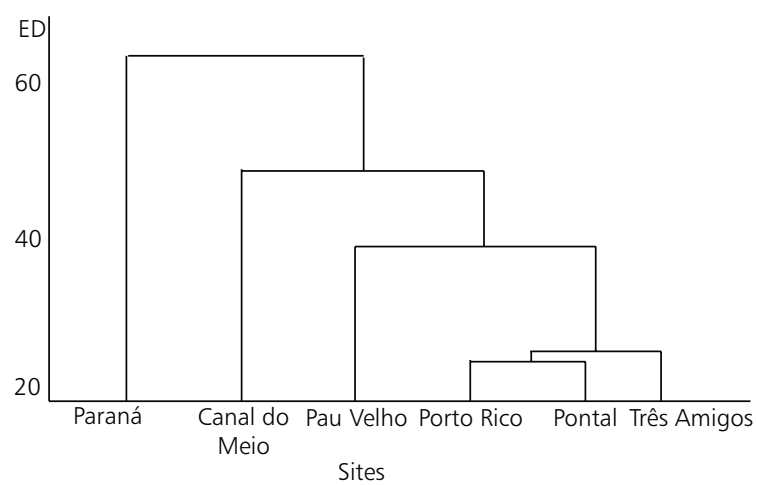

Fig. 5 - Dendrogram of Euclidian distances (ED) based on the diet of Roeboides paranensis specimens caught at five pools and one site in Rio Paraná.

Sazima \& Machado (1982) commented that among the species of Roeboides, $R$. prognathus is the most specialized, with morphological and behavioral characteristics that are clearly adapted to this mode of life.

Although no quantitative data are available regarding the invertebrates found in the stomachs, consumption of invertebrates is probably related to the abundance of these items in the localities sampled. Of the microcrustaceans, cladocerans are most commonly consumed perhaps because of their low escape ability (Towsend \& Winfield, 1985). Aquatic Hemiptera (Gerridae) because of their swimming movements on the surface film of the water, are easily detected.

The high similarity of different locations, regarding the food content, was not related to the proximity of the pools, since there are considerable distance (more than 1,000 m) from one another. It can not also be attributed to the physical structure of the environment, given that the pools differ considerably according to the amount of cover and abiotic conditions (Okada, 1995). Thus, we can conclude that this species use basically the same item independently of the site.

Acknowledgments - Thanks are due to Nupélia, Itaipu Binacional and PEA for logistic and financial support. This paper benefited from comments and suggestions of Heraldo A. Britski, MZUSP (Museu de Zoologia da Universidade de São Paulo), Kirk Winemiller (Texas A\&M University) and Sidinei M. Thomaz (UEM-Nupélia).

\section{REFERENCES}

DINGERKUS, G. \& UHLER, L. D., 1977, Enzyme clearing of alcian blue stained small vertebrates for demonstration of cartilage. Stain Technol., 52(4): 229-232.

GÉRY, J., 1977, Characoids of the word. T. F. H. Publications, Neptune City, 672p.

HYNES, H. B. N., 1950, The food of freshwater sticklebacks (Gasterosteus aculeatus and Pigosteus pungitius), with a review of methods used in studies of the food fishes. J. Anim. Ecol., 19(1): 36-56.

MIQUELARENA, A. M., 1986, Estudio de la dentición en peces caracoideos de la República Argentina. Biol. Acuática, 8: 1-60.

OKADA, E. K., 1995, Diversidade e abundância de peixes em corpos de água sazonalmente isolados na planície alagável do alto rio Paraná e fatores ambientais relacionados. Dissertação de Mestrado em Ecologia de Ambientes Aquáticos Continentais, Departamento de Biologia, Universidade Estadual de Maringá, Maringá, 24p.

PETERSON, C. C. \& WINEMILLER, K. W., 1997, Ontogenetic diet shifts and scale-eating in Roeboides dayi, a neotropical characid. Environ. Biol. Fishes, 49: $111-118$.

POTTHOFF, T., 1984, Clearing and staining techniques. In: H. G. Moser, W. J. Richards, D. M. Cohen, M. P. Fahay-Jr., A. W. Kendall \& S. L. Richardson (eds.), Ontogeny and Systematics of Fishes. American Society of Ichthyologists and Herpetologists, (Spec. Publ.; n.1), Lawrence, Kansas, pp. 35-37.

ROBERTS, T. R., 1967, Tooth formation and replacement in characoid fishes. Stanford Ichthyol. Bull., 8(4): 231-249. 
ROBERTS, T. R., 1970, Scale-eating American characoid fishes, with special reference to Probolodus heterostomus. Proc. Calif. Acad. Sci., 38(20): 383-390.

SAZIMA, I., 1983, Scale-eating in characoids and other fishes. Environ. Biol. Fishes, 9(2): 87-101.

SAZIMA, I. \& MACHADO, F. A., 1982, Hábitos e comportamento de Roeboides prognathus, um peixe lepidófago (Osteichthyes, Characoidei). Bolm. Zool., 7: $35-56$.
TAYLOR, W. R., 1967, An enzyme method of clearing and staining small vertebrates. Proc. U. S. Nat. Mus., 122: $1-17$.

TOWSEND, C. R. \& WINFIELD, I. J., 1985, The application of optimal foraging theory to feeding behavior in fish. In: P. Tytler \& P. Calow (eds.), Fish Energetics: New Perspectives. Croom Helm, London, pp. 6798. 